\title{
Preparation of some new benzo[d]thiazole derivatives
}

\author{
Duong Quoc Hoan ${ }^{1 *}$, Vu Thi Anh Tuyet ${ }^{2}$, Le Thanh Duong', Nguyen Hien ${ }^{1}$ \\ ${ }^{1}$ Department of chemistry, Hanoi National University of Education \\ ${ }^{2}$ Department of science, Lang Son College of Education
}

Received 9 February 2017; Accepted for publication 28 August 2017

\begin{abstract}
In this work, four new benzo[ $d]$ thiazole derivatives were synthesized successfully from vanillin. Nitration of vanillin gave nitrovanillin followed by cyclization reaction with $o$-aminothiophenol under microwave irradiation in 4 minutes to give nitroaromatic compound 3 . The reduction to convert the nitro group to amino group was optimized. It was found that $\mathrm{Fe} / \mathrm{con} . \mathrm{HCl}$ in ethanol was the best condition for this case about both yield ( $95 \%)$ and simple procedure to give compound $\mathbf{4}$ as a salt. Acetylation occurs at both phenolic hydroxyl group and amino group of the salt $\mathbf{4}$ to form $\mathrm{N}, \mathrm{O}$-acetyl compound $\mathbf{5}$. Under mild hydrolysis $\mathbf{5}$ produces $\mathrm{N}$-acetyl compound $\mathbf{6}$. The structures of these compounds were established by IR, ${ }^{1} \mathrm{H}$ and ${ }^{13} \mathrm{C}$ NMR and mass spectral analyses.
\end{abstract}

Keywords. Benzo[d]thiazole, vanillin, reduction, microwave.

\section{INTRODUCTION}

Benzo $[d]$ thiazole was first synthesized in 1880 by Hofmann A. W from formic acid and $O$ aminothiphenol [1]: however, the application of benzo $[d]$ thiazole derivatives has been studied recently and in the past two decades they have been extensively studied for their anticancer activity [2,3,4]. For example, 2-(4-aminophenyl) benzothiazoles (A), an amino aromatic compound, and their corresponding $\mathrm{N}$-acetylated derivatives (B) have shown surprisingly remarkable anticancer activity against certain cancer cell lines particularly against breast, colon and ovarian cell lines in vitro anticancer screening $[5,6]$. Surprisingly, compound C exhibited remarkably potent anticancer activity
[7]. In 2013, J. Pan et al. showed that complexes D of $\operatorname{Re}$ metal containing benzo[ $[d]$ thiazole with various substituent Rs exhibited the lipophilicities in range $\log \mathrm{P}_{\mathrm{C} 18}=1-4$, their binding affinities $\left(\mathrm{K}_{\mathrm{i}}=30\right.$ $617 \mathrm{nM})$ to $A \beta_{1-40}$ fibrils. Nitroaromatic compounds play an essential role not only in organic synthesis but also in human life. For instance, they are pesticides, bacterial degradation, etc. [8]. Therefore, in this work, benzo $[d]$ thiazole derivatives $\mathbf{E}$ were designed by retaining the structure of vanillin and connecting with a benzo $[d]$ thiazole ring synthesized from vanillin, figure 1 . To take advantages of amino, amide and nitroaromatic compounds, R1 is either $\mathrm{NO}_{2}$ group, an amino group or an acetamido groups. $\mathrm{R} 2$ is an acetyl group or a hydrogen atom as vanillin moiety.<smiles>COc1cc(-c2nc3ccccc3s2)ccc1N</smiles>

A<smiles>COc1ccc(-c2nc3ccc(F)cc3s2)cc1OC</smiles>

C<smiles>COc1cc(-c2nc3ccccc3s2)ccc1NC(C)=O</smiles>

B

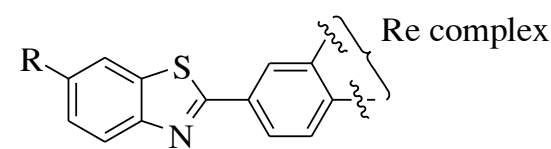

D<smiles>[R20]c1cc(-c2nc3ccccc3s2)cc([R])c1OC</smiles>

Benzo $[d]$ thiazole- Aromatic ring making the core structure

Figure 1: Examples of benzo[d]thiazole derivatives and Design target compounds $\mathbf{E}$ 


\section{EXPERIMENTAL}

\subsection{General}

Solvents and other chemicals were purchased from Sigma-Aldrich, Merck and used as received, unless otherwise indicated. The ${ }^{1} \mathrm{H}$ NMR and ${ }^{13} \mathrm{C}$ NMR spectra were recorded on the Bruker Avance 500 NMR spectrometer in deuterated solvents such as $\mathrm{CDCl}_{3}, \mathrm{DMSO}$, and or $\mathrm{D}_{2} \mathrm{O}$. Chemical-shift data for each signal was reported in ppm unit. IR spectra were recorded on the Mattson 4020 GALAXY Series FT-IR. Mass spectra were obtained from Mass Spectrometry Facility of The Vietnam Academy of Science and Technology on LC-MSDTrap-SL spectrometer.

\subsection{Synthetic procedure}

\subsubsection{Synthesis of 4-hydroxy-3-methoxy-5- nitrobenzaldehyde (2) [9, 10]}

Concentrated $\mathrm{HNO}_{3}(2 \mathrm{~mL})$ was carefully added to a cooled $\left(5^{\circ} \mathrm{C}\right)$ solution of vanillin $(5 \mathrm{~g}, 33 \mathrm{mmol})$ and acetic acid $(50 \mathrm{~mL})$ over a period of $30 \mathrm{~min}$. The gold colored precipitate that formed was filtered, washed with water, and allowed to dry $(5.21 \mathrm{~g}, 80$ $\%)$ : mp. $171{ }^{\circ} \mathrm{C}$.

\subsubsection{Synthesis of 4-(benzo[d]thiazol-2-yl)-2- methoxy-6-nitrophenol (3)}

4-Hydroxy-3-methoxy-5-nitrobenzaldehyde (2, 0.55 $\mathrm{g}, 3.3 \mathrm{mmol})$ and 2-aminothiophenol $(0.35 \mathrm{~mL}, 3.3$ mmol) were mixed well in an $100 \mathrm{~mL}$ beaker. The resulting mixture was irradiated with a domestic microwave oven for 4 minutes at $400 \mathrm{~W}$ level. The mixture was stood for cooling down at room temperature and solidifying. The by recrystallization from hot ethyl acetate/n-hexane (1:1) yielded the title compound $\mathbf{3}$ as a pale pink solid (0.98 g, $98 \%, 302.3 \mathrm{~g} / \mathrm{mol})$, mp. $163{ }^{\circ} \mathrm{C}$. IR $\left(\mathrm{cm}^{-1}\right)$ : 3435 (br), 3100, 2914, 2852, 1613, 1545, 1430, 1263, 1143, 1021. ${ }^{1} \mathrm{H}$ NMR (DMSO-d6, $\left.500 \mathrm{MHz}\right) \delta$ (ppm): $8.14(\mathrm{~d}, J=8.0 \mathrm{~Hz}, 1 \mathrm{H}), 8.08(\mathrm{~s}, 1 \mathrm{H}), 8.06$ $(\mathrm{d}, J=8.0,1 \mathrm{H}), 7.83(\mathrm{~s}, 1 \mathrm{H}), 7.55(\mathrm{t}, J=7.5,1 \mathrm{H})$, $7.46(\mathrm{t}, J=7.5,1 \mathrm{H}), 4.02(\mathrm{~s}, 3 \mathrm{H}) ;{ }^{13} \mathrm{C} \mathrm{NMR}$ (DMSO-d6, $125 \mathrm{MHz}) \delta$ (ppm): 165.44, 153.34, 150.12 , 145.08, 137.30, 134.50, 126.78, 125.60, $123.26,122.76,122.35,115.38,113.01,56.87$; ESIMS m/z: $273\left[\mathrm{C}_{14} \mathrm{H}_{11} \mathrm{NO}_{3} \mathrm{~S}\right]^{+}$and $271\left[\mathrm{C}_{14} \mathrm{H}_{9} \mathrm{NO}_{3} \mathrm{~S}\right]^{-}$.

2.2.3. Synthesis of 2-amino-4-(benzo[d]thiazol-2-yl)6-methoxyphenol hydrochloride (4)
Iron powder $(8 \mathrm{~g}, 0.14 \mathrm{~mol})$ was added portionwise with stirring to a hot mixture of 4-(benzo[ $[d]$ thiazol2-yl)-2-methoxy-6-nitrophenol (3) (6.4 g, 20 mmole) in ethanol $(20 \mathrm{ml})$ and concentrated hydrochloric acid $(30 \mathrm{ml})$ at reflux temperature. After completion of the addition, the refluxing was continued for 6 hours. Upon cooling a yellow precipitate formed, which was filtered off, washed with ethanol, dried to yield the title product as a yellow powder $(5.6 \mathrm{~g}$, $95 \%, 308.8 \mathrm{~g} / \mathrm{mol}$ ) mp: decomposed at $280{ }^{\circ} \mathrm{C}$. IR $\left(\mathrm{cm}^{-1}\right): 3100,2954,2797,3100-2500$ (br), 1540, 1401, 1170. ${ }^{1} \mathrm{H}$ NMR $\left(\mathrm{D}_{2} \mathrm{O}, 500 \mathrm{MHz}\right) \delta(\mathrm{ppm})$ : $7.31(\mathrm{~d}, J=8.0 \mathrm{~Hz}, 1 \mathrm{H}), 7.15(\mathrm{~s}, 1 \mathrm{H}), 7.94(\mathrm{~d}, J=$ $5.0 \mathrm{~Hz}, 1 \mathrm{H}), 6.80(\mathrm{~d}, J=6.5 \mathrm{~Hz}, 1 \mathrm{H}), 6.75(\mathrm{~s}, 1 \mathrm{H})$, $6.40(\mathrm{~s}, 1 \mathrm{H}), 3.46(\mathrm{~s}, 3 \mathrm{H}) ;{ }^{13} \mathrm{C}$ NMR $\left(\mathrm{D}_{2} \mathrm{O}, 125\right.$ MHz) $\delta$ (ppm): 167.31, 149.09, 147.60, 142.87, $137.30,132.08,126.78,125.58,121.45,119.88$, $117.45,114.05,108.90,55.86$. ESI-MS $m / z: 273$ $\left[\mathrm{C}_{14} \mathrm{H}_{13} \mathrm{~N}_{2} \mathrm{O}_{2} \mathrm{~S}\right]^{+}$and $271\left[\mathrm{C}_{14} \mathrm{H}_{11} \mathrm{~N}_{2} \mathrm{O}_{2} \mathrm{~S}\right]^{-}$.

\subsubsection{Synthesis of 2-acetamido-4-(benzo[d]thiazol- 2-yl)-6-methoxyphenyl acetate (5)}

To a solution of 2-amino-4-(benzo[d]thiazol-2-yl)-6methoxyphenol hydrochloride $(4)(0.3 \mathrm{~g}, 1 \mathrm{mmol})$ and triethyl amine $(0.42 \mathrm{~mL}, 3 \mathrm{mmol})$ was added acetic anhydride $(0.3 \mathrm{~mL}, 2.5 \mathrm{mmol})$ in DMF (5 $\mathrm{mL}$ ). The resulting solution was stirred at room temperature for $1 \mathrm{~h}$. The solvent was evaporated in vacuum. Water was added to obtain solid. Recrystallization in ethanol $96 \%$ gave 2-acetamido-4(benzo[ $d]$ thiazol-2-yl)-6-methoxyphenyl acetate (5) as a white crystal in $80 \%(285 \mathrm{mg}, 356.4 \mathrm{~g} / \mathrm{mol})$. IR $\left(\mathrm{cm}^{-1}\right): 3347,3169,2923,2837,1735,1692,1605$, 1543, 1217, 1103. ${ }^{1} \mathrm{H}$ NMR (DMSO-d6, $\left.500 \mathrm{MHz}\right) \delta$ (ppm): $9.58(\mathrm{~s}, 1 \mathrm{H}), 8.43(\mathrm{~s}, 1 \mathrm{H}), 8.15(\mathrm{~d}, J=8.0$ $\mathrm{Hz}, 1 \mathrm{H}), 8.09(\mathrm{~d}, J=8.0 \mathrm{~Hz}, 1 \mathrm{H}), 7.56(\mathrm{t}, J=8.0$ $\mathrm{Hz}, 1 \mathrm{H}), 7.52(\mathrm{~s}, 1 \mathrm{H}), 7.47$ (t, $J=7.5 \mathrm{~Hz}, 1 \mathrm{H}), 3.90$ $(\mathrm{s}, 3 \mathrm{H}), 2.33(\mathrm{~s}, 3 \mathrm{H}), 2.14(\mathrm{~s}, 2 \mathrm{H}) .{ }^{13} \mathrm{C}-\mathrm{NMR}$ (DMSO-d6, $125 \mathrm{MHz}) \delta$ (ppm): 169.11, 167.89, $166.72,153.45,151.71,134.56,132.69,131.5$, $130.42,126.70,125.58,122.88,122.36,113.89$, 105.51, 56.29, 23.85, 20.79. ESI-MS $\mathrm{m} / z: 357$ $\left[\mathrm{C}_{18} \mathrm{H}_{17} \mathrm{~N}_{2} \mathrm{O}_{4} \mathrm{~S}\right]^{+}$and $355\left[\mathrm{C}_{18} \mathrm{H}_{15} \mathrm{~N}_{2} \mathrm{O}_{4} \mathrm{~S}\right]^{-}$.

\subsubsection{Synthesis of $N$-(5-(benzo[d]thiazol-2-yl)-2- hydroxy-3-methoxyphenyl)acetamide (6)}

To a solution of 2-acetamido-4-(benzo[ $d]$ thiazol-2yl)-6-methoxyphenyl acetate (5) $(0.356 \mathrm{~g}, 1 \mathrm{mmol})$ in $\mathrm{MeOH} / \mathrm{H}_{2} \mathrm{O}(1: 2),(5 \mathrm{~mL})$ was added $\mathrm{LiOH}(60$ $\mathrm{mg}, 2.5 \mathrm{mmol})$. The mixture was refluxed until all solid was dissolved completely, then acidified with (1:1) $\mathrm{HCl}$ up to $\mathrm{pH}=5$. The precipitate was 
collected as a white crystal (0.3 g, $95 \%)$, mp: 172 ${ }^{\circ} \mathrm{C}$. IR $\left(\mathrm{cm}^{-1}\right): 3325$ (br), 3080, 2928, 2817, 2797, 1690, 1542, 1401, 1179; ${ }^{1} \mathrm{H}-\mathrm{NMR}\left(\mathrm{CDCl}_{3}, 500\right.$ MHz) $\delta(\mathrm{ppm}): 8.33(\mathrm{~s}, 1 \mathrm{H}), 8.00(\mathrm{~d}, J=8.5 \mathrm{~Hz}$, $1 \mathrm{H}), 7.86(\mathrm{~d}, J=7.5 \mathrm{~Hz}, 1 \mathrm{H}), 7.79(\mathrm{br}, 1 \mathrm{H}), 7.53(\mathrm{~d}$, $J=1.5 \mathrm{~Hz}, 1 \mathrm{H}), 7.45(\mathrm{t}, J=8.0 \mathrm{~Hz}, 1 \mathrm{H}), 7.34(\mathrm{t}, J=$ $8.0 \mathrm{~Hz}, 1 \mathrm{H}), 7.18$ (s, 1H), 3.96 (s, 3H), 2.26 (s, 3H); ${ }^{13} \mathrm{C}-\mathrm{NMR} \quad\left(\mathrm{CDCl}_{3}, 125 \mathrm{MHz}\right) \quad \delta$ (ppm):169.18, $168.14,154.02,147.62,138.06,135.08,132.50$, $126.21,125.72,124.91,122.78,121.59,113.80$, $105.60, \quad 56.44, \quad 24.50 ; \quad$ ESI-MS $\quad \mathrm{m} / \mathrm{z}: 315$ $\left[\mathrm{C}_{16} \mathrm{H}_{15} \mathrm{~N}_{2} \mathrm{O}_{3} \mathrm{~S}\right]^{+}, 313\left[\mathrm{C}_{16} \mathrm{H}_{13} \mathrm{~N}_{2} \mathrm{O}_{3} \mathrm{~S}\right]^{-}$.

\section{RESULTS AND DISCUSSION}

\subsection{Synthesis}

The series of benzo[ $d]$ thiazole derivatives was driven as shown in the Scheme 1. First, nitration of vanillin was carried out in $80 \%$ yield to give nitrobenzaldehyde 2 . Then, the benzo $[d]$ thiazole cyclization was furnished in 4 minutes when the nitrobenzaldehyde $\mathbf{2}$ was treated with $o$ aminothiophenol to yield nitroaromatic compound $\mathbf{3}$ in $98 \%$ yield.<smiles></smiles><smiles>COc1cc(C=O)cc([N+](=O)[O-])c1O</smiles>

2, $80 \%$

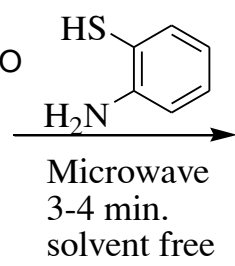<smiles>COc1cc(-c2nc3ccccc3s2)cc([N+](=O)[O-])c1OC</smiles>

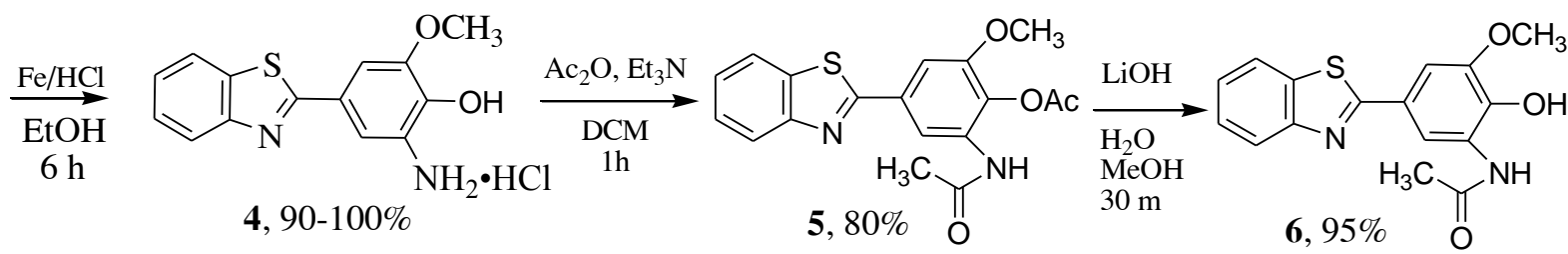

Scheme 1: Synthesis of the target compounds

Reduction of nitro group to amino group was optimized by using some classic methods, table 1 . All entries were carried out up to 20 hours and monitored with thin layer chromatography (TLC). In the first entry, $\mathrm{Na}_{2} \mathrm{~S}_{2} \mathrm{O}_{4} / \mathrm{NaOH}$ reagents were used [11]. Unfortunately, as soon as the reagents added, the reaction solution turned black due to the reason that in the basic condition, free aniline 3 ' was formed and oxidized by oxygen in the air, scheme 2 . Nevertheless, there was a question: why was amine 3' oxidized easily? Because the benzene ring contains 4 donating electron groups $-\mathrm{OCH}_{3},-\mathrm{O}^{-}$, $-\mathrm{NH}_{2}$ and benzo[d]thiazole ring [12] that raises the electron density on the benzene ring, consequently, it is oxidized quickly called the aniline black.<smiles>COc1cc(-c2nc3ccccc3s2)cc([N+](=O)[O-])c1O</smiles>

Scheme 2: Aniline black observation

This result helps us think about the use of acidic conditions [13] and save the amine as a salt form. Hence, the entries 2-7 were treated with either concentrated $\mathrm{HCl}$ or $\mathrm{NH}_{4} \mathrm{Cl}$ in water and in ethanol. It was found thaethanol was better solvent than water since ethanol could dissolve substrates well but could not dissolve salt form 4. In comparison of $\mathrm{Zn}$ with $\mathrm{Fe}$, both gave good yields, but it was difficult to separate the unreacted $\mathrm{Zn}$ out of the mixture, while iron could be attached to the stirring bar so the unreacted iron was removed just by washing the stirring bar simply. Finally, the salt $\mathbf{4}$ was easily filtered and dried for next step without further purification. Surprisingly, $\mathrm{Fe} / \mathrm{NH}_{4} \mathrm{Cl}$ [14] did not work in this case because the acidity of ammonium chloride is weaker than the salt form $\mathbf{4}$ and the free amine was formed then oxidized 
immediately resulting in black solution as observed.

reaction due to small solubility of substrates in water. All entries taken place in water were slowly or no

Table 1: Reduction optimization results

\begin{tabular}{|c|c|c|c|c|c|}
\hline Entry & Reagent & Solvent & Time (h) & Observation & Yield (\%) \\
\hline $\mathbf{1}$ & $\mathrm{Na}_{2} \mathrm{~S}_{2} \mathrm{O}_{4} / \mathrm{NaOH}$ & $\mathrm{H}_{2} \mathrm{O}$ & 0.5 , reflux & Black solution & 0 \\
\hline $\mathbf{2}$ & $\mathrm{Zn} /$ con. $\mathrm{HCl}$ & $\mathrm{H}_{2} \mathrm{O}$ & 14, reflux & Yellow solution & 75 \\
\hline $\mathbf{3}$ & $\mathrm{Zn} /$ con. $\mathrm{HCl}$ & $\mathrm{C}_{2} \mathrm{H}_{5} \mathrm{OH}$ & 7, reflux & Yellow solid & 95 (impure) \\
\hline $\mathbf{4}$ & $\mathrm{Fe} / \mathrm{NH}_{4} \mathrm{Cl}$ & $\mathrm{H}_{2} \mathrm{O}$ & $18,50^{\circ} \mathrm{C}$ & Black solution & 0 \\
\hline $\mathbf{5}$ & $\mathrm{Fe} / \mathrm{NH}_{4} \mathrm{Cl}$ & $\mathrm{C}_{2} \mathrm{H}_{5} \mathrm{OH}$ & $20,50^{\circ} \mathrm{C}$ & Black solution & 0 \\
\hline $\mathbf{6}$ & $\mathrm{Fe} /$ con. $\mathrm{HCl}$ & $\mathrm{H}_{2} \mathrm{O}$ & 12, reflux & Yellow solution & 70 \\
\hline $\mathbf{7}$ & $\mathrm{Fe} /$ con. $\mathrm{HCl}$ & $\mathrm{C}_{2} \mathrm{H}_{5} \mathrm{OH}$ & 7, reflux & Yellow solid & 95 (pure) \\
\hline
\end{tabular}

As there was an amine salt $\mathbf{4}$ in hand, it was treated with acetic anhydride to form $N, O$-diacetyl compound $\mathbf{5}$ in $80 \%$ yield. Then $N, O$-diacetyl compound 5 was hydrolyzed in methanol and $\mathrm{LiOH}$ giving $N$-acetyl amide 6 in $95 \%$ yield.

\subsection{Structure determination}

Nitrovanillin 2 was checked for melting point, and it matched with the previous report $[9,10]$. Because compounds 3, 4, 5 and 6 are new, so they were recorded for IR, MS and NMR spectra to determine their structures. Spectroscopic data were analyzed carefully [15]. First, IR spectrum of nitro compound 3 did not show the vibration of carbonyl group of vanillin that indicated cyclization of benzo $[d]$ thiazole occurred. IR of compound 4 showed broad band of $\mathrm{N}-\mathrm{H}$ bond in range 3100-2500 $\mathrm{cm}^{-1}$ that was for N-H vibration in the ammoniumlike form. IR spectrum of compound $\mathbf{5}$ showed two signals of carbonyl groups at 1735 and $1692 \mathrm{~cm}^{-1}$, that indicated two acetyl groups must be in the structure of $\mathrm{N}, \mathrm{O}$-diacetyl compound $\mathbf{5}$. IR spectrum of $N$-acetyl amide 6 showed a band at $1690 \mathrm{~cm}^{-1}$ and vibration of $\mathrm{N}-\mathrm{H}$ amide at $3325 \mathrm{~cm}^{-1}$ and overlapped with vibration of $\mathrm{O}-\mathrm{H}$ bond. Next, ${ }^{1} \mathrm{H}$ NMR spectrum of nitroaromatic compound $\mathbf{3}$ and salt $\mathbf{4}$ showed 6 protons of aromatic rings and 3 protons of methoxy group; however, ${ }^{1} \mathrm{H}$ NMR spectra of both the nitroaromatic compound $\mathbf{3}$ and the salt $\mathbf{4}$ did not show a proton of $\mathrm{OH}$ group since it appeared in the block of solvent peaks. ${ }^{13} \mathrm{C}$ NMR spectrum of compound 4 showed 14 peaks for 14 carbon atoms. Meanwhile, ${ }^{1} \mathrm{H}$ NMR and ${ }^{13} \mathrm{C}$ NMR of $N, O$-diacetyl compound 5 showed two signals at $\delta 2.33 \mathrm{ppm}$ (s, $3 \mathrm{H})$ and $2.14 \mathrm{ppm}(\mathrm{s}, 3 \mathrm{H})$ and 2 peaks in the weak field at $169.11 \mathrm{ppm}$ and $167.98 \mathrm{ppm}$ assigned for two carbonyl groups of acetyl amide and acetyl ester. Other two peaks at $\delta 23.85 \mathrm{ppm}$ and $\delta 20.79$ ppm belonged to two methyl groups of these acetyl groups. After hydrolysis of $\mathrm{N}, \mathrm{O}$-diacetyl compound 5 to obtain $N$-acetyl compound $6,{ }^{1} \mathrm{H}$ NMR and ${ }^{13} \mathrm{C}$ NMR of $N$-acetyl compound $\mathbf{6}$ showed only a peak at $\delta 2.25 \mathrm{ppm}$ for methyl of the acetyl amide associated with the peak at $\delta 25.50 \mathrm{ppm}$ on the ${ }^{13} \mathrm{C}$ NMR spectrum.

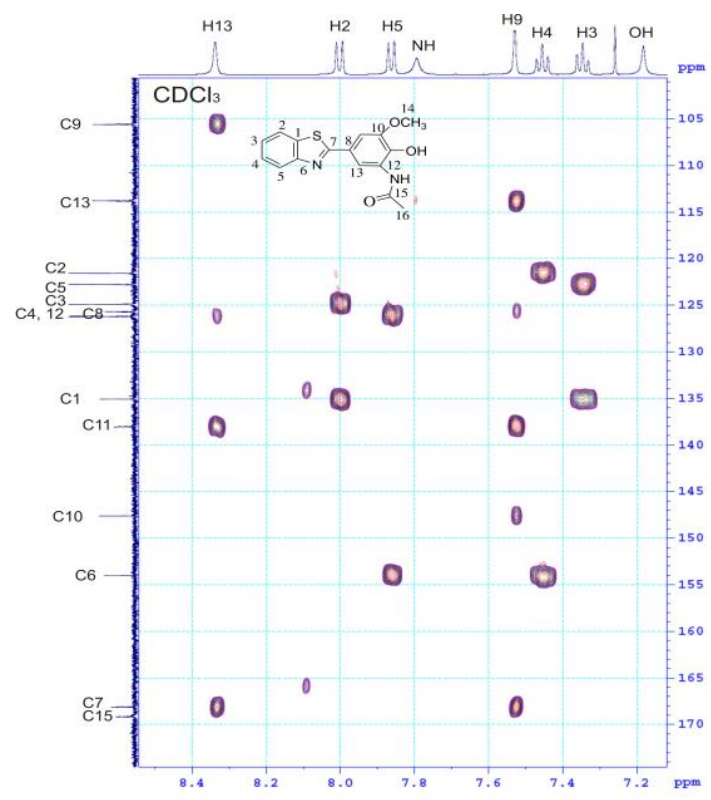

Figure 2: A part of HMBC spectrum

Then, in order to assign each carbon and hydrogen in the target product 6, HSQC and HMBC spectra were studied carefully. First, HSQC spectrum indicated cross-peaks of carbons bearing protons. Although, there were still some pairs of carbons or protons that were difficult to indentify such as $\mathrm{C} 7 / \mathrm{C} 15$; $\mathrm{C} 3 / \mathrm{C} 4$; $\mathrm{C} 1 / \mathrm{C} 6$; $\mathrm{C} 9 / \mathrm{C} 13$; C10/C12; $\mathrm{H} 4 / \mathrm{H} 3 ; \mathrm{H} 9 / \mathrm{H} 13 ; \mathrm{H} 2 / \mathrm{H} 5$ and $\mathrm{NH} / \mathrm{OH}, \mathrm{HMBC}$ spectrum distinguished all. For example, $\mathrm{C} 7 \mathrm{had}$ HMBC cross-peaks with $\mathrm{H} 9$ and $\mathrm{H} 13$ but $\mathrm{C} 15$ did not. In addition, $\mathrm{C} 15$ had an HMBC cross-peak with H15, on the other hand, C7 hadn't got further peaks. 
The most difficult assignment was identification of C13/C19 and H13/H9. Fortunately, it was easily to find $\mathrm{H} 14$ that had an HMBC cross-peak with $\mathrm{H} 9$. Therefore, $\mathrm{H} 13$ and $\mathrm{C} 13$ were identified and so on. Other assignments were shown in the figure 2.

Finally, compounds 3, 4, 5 and 6 were recorded for mass spectroscopy. MS spectrum of compound $\mathbf{3}$ indicated the first fragment was $\mathrm{NO}[\mathrm{M}-30+\mathrm{H}]$ at $\mathrm{m} / \mathrm{z} 273 \mathrm{au},[\mathrm{M}-30-\mathrm{H}]$ at $\mathrm{m} / \mathrm{z} 271$ au that matched with calculated. MS spectra of compounds 4, 5 and 6 also confirmed the expected structure as shown in the experimental section.

\section{CONCLUSION}

Four new benzo $[d]$ thiazole derivatives $(\mathbf{3}, \mathbf{4}, \mathbf{5}$ and 6) were successfully synthesized in high yield. Fe powder and concentrated $\mathrm{HCl}$ in ethanol was the best condition for converting nitro group to amine group in our case. All reactions worked under simple conditions and gave excellent yields. Structures of compounds nitroaromatic $\mathbf{3}$, salt $\mathbf{4}, N, O$-diacetyl $\mathbf{5}$ and $N$-acetyl $\mathbf{6}$ were confirmed with IR, NMR and MS analyses.

Acknowledgements. This research is supported by Hanoi National University of Education (HNUE) under the project code SPHN16-25TT.

\section{REFERENCES}

1. Hofmann A. W. Uebereine Reihe aromatischer, den Senfölen und Sulfocyanaten isomerer Basen, Chemische Berichte, 13, 8-22 (1880).

2. Caleta I., Kralj M., Branimir Bertosa B., Sanja Tomic S., Pavlovic G., Pavelic K., Karminski-Zamola G. Novel Cyano- and Amidinobenzothiazole Derivatives: Synthesis, Antitumor Evaluation, and Xray and Quantitative Structure, Activity Relationship (QSAR) Analysis, J. Med. Chem., 52, 1744 (2009).

3. Chung Y., Shin Y.-K., Zhan C.-G., Lee S., Cho H. Synthesis and evaluation of antitumor activity of 2and 6-[(1,3-benzothiazol-2-yl)aminomethyl]-5,8dimethoxy-1,4-naphthoquinone derivatives, Arch. Pharmacol. Res., 27, 893 (2004).

4. Yoshida M., Hayakawa I., Hayashi N., Agatsuma T., Oda Y., Tanzawa F., Iwasaki S., Koyama K., Furukawa H., Kurakata S. Synthesis and biological evaluation of benzothiazole derivatives as potent antitumor agents, Bioorg. Med. Chem. Lett., 15,
3328 (2005).

5. Bradshaw T. D., Stevens M. F. G., Westwell A. D. The Discovery of the Potent and Selective Antitumour Agent 2-(4-Amino-3-methylphenyl) benzothiazole (DF 203) and Related Compounds, Curr. Med. Chem., 8, 203 (2001).

6. Hutchinson I., Chua M.-S., Browne H. L., Trapani, V., Bradshaw T. D., Westwell A. D., Stevens, M. F. G. Antitumor Benzothiazoles: Synthesis and in Vitro Biological Properties of Fluorinated 2-(4Aminophenyl)benzothiazoles, J. Med. Chem., 44, 1446 (2001).

7. Mortimer C. G., Wells G., Crochard J.-P., Stone E. L., Bradshaw T. D., Stevens M. F. G., Westwell A. D, Antitumor Benzothiazoles: 2-(3,4Dimethoxyphenyl)-5-fluorobenzothiazole (GW 610, NSC 721648), a Simple Fluorinated 2Arylbenzothiazole, Shows Potent and Selective Inhibitory Activity against Lung, Colon, and Breast Cancer Cell Lines, J. Med. Chem., 49, 179 (2006).

8. Kou-San Ju and Rebecca E. Parales. Nitroaromatic Compounds, from Synthesis to Biodegradation, Microbiol. Mol. Biol. Rev., 74(2), 250 (2010).

9. Thorata B. R., Mustapha Mandewalea, Sharda Shelke, Prasad Kamat, R. G. Atrama, Mahesh Bhalerao and R. Yamgara. Synthesis of novel Schiff bases of 4hydroxy-3-methoxy-5-nitrobenzaldehyde and Development of HPLC Chromatographic Method for their analysis, J. Chem. Pharm. Res., 4(1), 14-17 (2012).

10. Karl B. and Eng W. T. Synthesis and evaluation of bifunctional nitrocatechol inhibitors of pig liver catechol-O-methyltransferase, Bioorg. Med. Chem., 13, 5740-5749 (2005).

11. Hoang Thi Tuyet Lan, Nguyen Hien, Nguyen Huu Dinh, Synthesis and structures of some azomethins from 2-methoxy-4-(3-methylfuroxan-4-yl)-5nitrophenoxy acetic acid, Vietnam Journal of Chemistry, 51(6 ABC), 141-145 (2013).

12. Zahradník P. Quantum-chemical study of electronic structure and transmission of substituent effect in benzothiazole derivatives, Chem. Papers, 44 (2), 145150 (1990).

13. Furniss B. S., Hannaford A. J., Smith P. W. G., Tatchell, A. R. Vogel's textbook of practical organic chemistry, $5^{\text {th }}$ ed., Pearson education limited (1989).

14. Sahoo S. S., Shukla S., Nandy S., Sahoo H. B. Synthesis of novel coumarin derivatives and its biological evaluations, European Journal of Experimental Biology, 2, 899-908 (2012).

15. Silverstein R. M., Webster F. X., Kiemle, D. J. Spectrometric identification of organic compounds, John Wiley \& Sons, Inc (2005).

\section{Corresponding author: Duong Quoc Hoan}

Department of Chemistry, Hanoi National University of Education

No. 136, Xuan Thuy Str., Cau Giay Dist., Ha Noi

E-mail: hoandq@hnue.edu.vn; Telephone: 0986778213. 